\title{
Records of interesting flies (Diptera) attracted to meat baited pyramidal trap on sapping stump of European walnut (Juglans regia) in Central Bohemia (Czech Republic)
}

\author{
Miroslav Barták \& Jindřich Roháček
}

Records of interesting flies (Diptera) attracted to meat baited pyramidal trap on sapping stump of European walnut (Juglans regia) in Central Bohemia (Czech Republic). - Čas. Slez. Muz. Opava (A), 60: 223-233.

\begin{abstract}
A pyramidal trap with combined bait is described and illustrated. The trap inserted above sapping stump of European walnut (Juglans regia) in a site in Central Bohemia near Uhlírské Janovice in 2010 yielded a rich spectrum of flies (Diptera). Records of 24 species most interesting from the faunistic, biological and nature conservancy point of view are given with comments upon their distribution and biology but a number of other captured species are also mentioned. Besides species developing in or attracted as adults to sap runs [e.g. Syrphidae: Ceriana conopsoides (Linnaeus, 1758), Aulacigastridae: three Aulacigaster spp., various Drosophilidae], other important components were formed by saproxylic [Xylomyidae: Solva marginata (Meigen, 1820), some Stratiomyidae, many Lonchaeidae, Milichiidae: Milichia ludens (Wahlberg, 1847), some Muscidae], mycophagous (some Asteiidae, Sphaeroceridae, Drosophilidae), necrophagous (some Sepsidae, Acartophtalmidae, Milichiidae, Sphaeroceridae) and saprophagous (some Sepsidae, Carnidae, Milichiidae, Sphaeroceridae) species, both latter attracted to meat-bait used in the trap. Aulacigaster falcata Papp, 1998 is the first record from Bohemia.
\end{abstract}

Key words: Diptera, pyramidal trap, sapping stump of Juglans regia, meat-bait, new records

\section{Introduction}

A number of various trapping methods were developed to capture flies (for review and descriptions of traps see e.g. McLean 2010). This contribution is aimed at describing one of recently developed (or modified) trapping device called the pyramidal trap (see Fig. 3), and at the presenting some results achieved by testing its effectiveness with regards to the qualitative composition of the species spectrum in the locality of Bláto near Uhlírské Janovice (Central Bohemia). Pyramidal (or pyramid) traps have formerly been used for monitoring and mass trapping of tsetse flies (e.g. Laveissière \& Grébaut 1990), but mostly they have been used as emergence traps buried in soil (Barták et al. 2008) or dipped in water for monitoring the biomass production of culicids (Walton 2009). Ježek \& Hájek illustrated (2007, Fig. 49) a pyramidal trap exposed above a decaying fir stump (without the collecting head).

The combination of several different substrates (attractive to flies) placed under the trap as described below (see Material and methods) was expected to enrich the species spectrum in the material trapped. The arrangement of the trap over the sapping stump of the European walnut was particularly interesting inasmuch as the affinities of flies to sap running down this tree have yet to be studied. Indeed, an array of species of various biology and microhabitat associations were collected, and records of the most interesting of these are given below.

\section{Material and methods}

Pyramidal trap (Fig. 3) of quadrangular pyramid shape (effective capture area = bottom of the trap $=1 \mathrm{~m}^{2}$ ) was made of fine polyester fabric (mesh less than $0.5 \mathrm{~mm}$ ). The collecting head was made of PET bottle with an opening drilled in its upper part where a short passage tunnel connected the trap with the collecting bottle. The connection of the trap with collecting bottle was made according to utility model "Insect trap" No. 20571 (Industrial property office of the Czech Republic): polyester fabric of the upper part of the trap was fixed between middle and outer of the three concentric cylinders made of small PET bottles; the entire passage tunnel 
was fixed to collecting bottle by a rope. The collecting bottle was filled with $70 \%$ ethylalcohol up to the lower margin of passage tunnel. Approximately once a month, trapped material was collected by carefully sieving the volume of collecting head by fine mesh and inserting samples into fresh $70 \%$ etylalcohol. The samples were stored in a freeze box $\left(-20^{\circ} \mathrm{C}\right)$ until processing. Only voucher specimens were selected from a large number of specimens (some 1 litre volume of material sampled each month) by the morphospecies method (but see eventually notices under individual species). Dry preparations were performed by a modified "Vockeroth's method" (for details see Barták 1997).

The trap was inserted above a freshly cut and sapping stump of a European walnut (Juglans regia) on the 27th of March, 2010. The trap was set with the small container filled by sawdust of a deciduous tree, in which bait (a decaying pig foot) was buried. Dates of samples: 24th April, 29th May, 3rd July (trap was dry due to long exposition), 11th July (meat bait removed), 11th August, 11th September, 17th October and 28th October 2010.

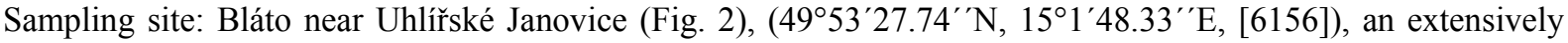
managed private garden (formerly a pond), with an alder wetland in one corner and two small brooks bordering it. A narrow vegetation corridor with old poplars occurs nearby (the closest are some $20 \mathrm{~m}$ from the trap, see Fig. $3)$. In the surrounding areas of Bláto there are huge agricultural fields and stubbles, and the nearest forests (mostly Norway spruce monocultures) are 2.4 to $2.7 \mathrm{~km}$ away and much "better" (more natural) forests are at distance of 5.1 to $7.2 \mathrm{~km}$.

\section{Results}

\section{XYLOMYIDAE}

\section{Solva marginata (Meigen, 1820)}

Material: 29.v.-3.vii., $1 \delta^{\Uparrow} 1$ ㅇ, 3.-19.vii., 3 ㅇ.

A Euroasian species, in Europe distributed from Great Britain and Sweden to Spain, Corsica, Italy and Bulgaria, also in the Near East and through western Siberia to Mongolia and China. The larvae are apparently saproxylic and micropantophagous and have been reared from beneath loose bark and rotten wood of deciduous trees (Nagatomi \& Rozkošný 1997). Out of the three xylomyid species known from the Czech Republic, this species is by far most common, however, in the trap we found surprisingly great number of adults (about 60), out of them above mentioned voucher specimens were selected.

\section{STRATIOMYIDAE}

\section{Neopachygaster meromelas (Dufour, 1841)}

Material: 3.-19.vii., 1ㅇ, 11.vii.-11.viii., 5 ㅇ.

A European species, known to occur from Fennoscandia to Spain, North Caucasus and Near East. Generally considered rare in Central Europe. The larvae live in the moist detritus beneath loose bark of dead deciduous trees (Rozkošný 1983).

In addition to this species two other saproxylic Stratiomyiidae were found in the trap, Pachygaster atra (Panzer, 1798) and P. leachii Curtis, 1842.

\section{SYRPHIDAE}

\section{Ceriana conopsoides (Linnaeus, 1758)}

Material: 11.vii.-11.viii., 1 \% .

A widely distributed Palaearctic species. In Central and West Europe it is very rare and decreasing with sporadic occurrence in lowland deciduous (Fagus/Quercus) forests with overmature trees. Saproxylic larvae live in sap runs and damp tree-holes of deciduous trees which agree with our record. Included in the recent regional Red list as an endangered species (Mazánek \& Barták 2005). 


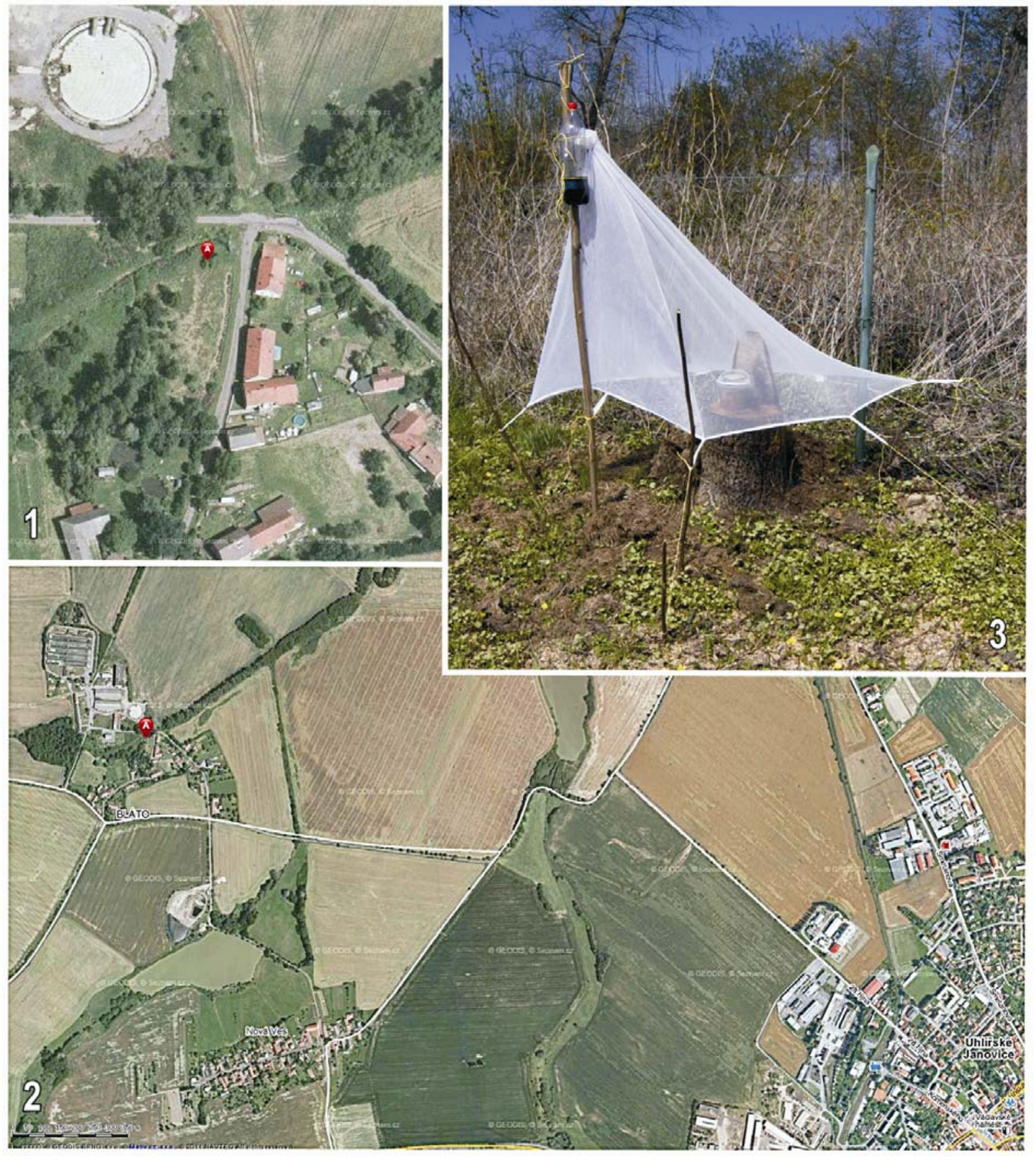

Fig. 1: Detailed image of the trap position in a garden in the village of Bláto (point A). Source: http://www.mapy.cz

Fig. 2: Trap situated at point A, in the village of Bláto, 2.7 km NWW of Uhliřské Janovice, Kolín district. Source: http://www.mapy.cz

Fig. 3: A pyramidal trap on sapping stump of European walnut (Juglans regia) with a meat-bait in plastic container. 


\section{Tropidia scita (Harris, 1776)}

Material: 29.v.-3.vii., 1q, 3.-19.vii., $1 \lesssim$.

A Transpalaearctic species. In Central Europe it is uncommon and local in waterside vegetation of pools, canals and beside slow-flowing rivers mostly in lowlands. Saprophagous larvae probably inhabit the rotting plant debris along the water's edge, occurring in reed beds, etc. of fens (Speight 2003). We found some 10 specimens in the trap from which above mentioned voucher specimens were selected.

\section{Eristalis intricaria (Linnaeus, 1758)}

Material: 3.-19.vii., 2 ㅇ.

A Eurosiberian species with subboreal distribution in Europe. In Central Europe it is moderately common, mostly in wetlands such as fens, fen carr, raised bogs, poorly-drained deciduous forests and humid, seasonally-flooded grasslands mostly in lowlands. Saprophagous larvae occur in semi-liquid mud and fen peat beside water, in field drains and slurry (Speight 2003).

\section{LONCHAEIDAE}

\section{Lonchaea tarsata Fallén, 1820}

Material: 3.-19.vii., 1 . .

The species known from western, southern and central Europe and in Finland, rare in the Czech Republic (Máca et al. 2005a). According to MacGowan \& Rotheray (2008) it is common in the Mediterranean but there has been no record of its biology. The present record from the sapping stump of walnut is the first indication concerning its biology, which may also explain its scarcity in the more northern parts of its distribution where walnut trees are allochthonnous and lacking in frequently sampled biotopes.

The representatives of Lonchaeidae occurred rather abundantly (135 specimens were selected from the rich material) in the trap and also the species richness (16 species) was high. Larvae of some of the collected species are scavengers on decaying herbs, viz. Lonchaea chorea (Fabricius, 1781) and Setisquamalonchaea fumosa (Egger, 1862). Chaetolonchaea dasyops (Meigen, 1826), Earomyia viridana (Meigen, 1826) and Protearomyia nigra (Meigen, 1826), all known to occur frequently outside woods, are probably also bound to the herbal layer. The above mentioned five species comprised about half of the number of lonchaeid specimens collected. The other half was represented by species developing in rotting wood. Lonchaea palposa Zetterstedt, 1847 (24 specimens), L. scutellaris Rondani, 1874 (18 specimens), L. fugax Becker, 1895 (10 specimens), L. peregrina Becker, 1895 (2 specimens) and L. stackelbergi Czerny, 1934 (1 specimen) are known to develop predominantly under bark of Populus spp. (which grow in close vicinity), and it may be presumed that the walnut tree, with similar wood consistence, may also serve as their breeding substrate. The remaining captured species are known to develop predominantly in other tree species (L. contigua Collin, 1953 and L. contraria Czerny, 1934 predominantly in beech, L. sylvatica Beling, 1873 in a wide variety of deciduous and coniferous trees) or their biology is largely unknown (L. hyalipennis Zetterstedt, 1847, L. tarsata Fallén, 1820, L. postica Collin, 1953). 


\section{SEPSIDAE}

\section{Meroplius minutus (Wiedemann, 1830)}

Material: 11.vii.-11.viii., 1 ㅇ․

Broadly distributed but everywhere rare Holarctic and Oriental species. Its finding in our trap agrees with previous observations that the species is attracted to carcasses and rotting fungi (Pont \& Maier 2002). Larva is a saprophagous generalist, living in excrements and various rotting organic substrates. The species is declining at least in Europe and, from this reason, it was listed as vulnerable in Czech Red list (Barták 2005).

\section{Sepsis pseudomonostigma Ursu, 1969}

Material: 11.viii.-11.ix., 1 ㅇ․

Little known, probably West Palaearctic species. In Europe with southern and southeastern distribution. It is a local species in Central Europe, from the Czech Republic firstly recorded by Barták et al. (1997). Interestingly, our trap was situated some $2 \mathrm{~km}$ from the place where mass occurrence of this species was observed.

\section{ODINIIDAE}

\section{Neoalticomerus formosus (Loew, 1844)}

Material: 24.iv.-29.v., 1 ㅇ.

A widespread Palaearctic species, in Europe known from Central Europe, Italy and Scandinavia. It is uncommon in the Czech Republic (Máca et al. 2005b). Larvae probably develop in galleries of wood-boring beetles (Ferrar 1987). Adults occur in humid deciduous forests and are attracted to exuding sap on trees.

In addition to this species also Odinia boletina (Zetterstedt, 1848), usually occurring on bracket fungi (particularly Fomes fomentarius), has been captured in the trap.

\section{AULACIGASTRIDAE}

\section{Aulacigaster falcata Papp, 1998}

Material: 27.iii.-24.iv., $1{ }^{\Uparrow} 1$ \%, 24.iv.-29.v., 2 .

This little known species has hitherto been recorded from Germany, Switzerland, Italy, Hungary, Croatia and Greece (Kassebeer 2001) and recently also from the Czech Republic (S. Moravia: Podyjí - Roháček \& Máca 2010). It is mainly associated with oak forests where its larvae develop in sapping runs of oak species (Quercus spp.), more rarely of other trees (Carpinus, Betula, Morus, Prunus), see Papp (1998) and Kassebeer (2001). The above record is the first from Bohemia; it is also important by demonstrating the association of the species with sap of an additional tree species (Juglans regia).

Interestingly, the species was found together (in the same dates) with both other Central European Aulacigaster species, viz. Aulacigaster leucopeza (Meigen, 1830) (common) and Aulacigaster pappi Kassebeer, 2001 (as frequent as A. falcata).

\section{STENOMICRIDAE}

\section{Podocera soniae (Merz \& Roháček, 2005)}

Material: 3.-19.vii., 1 +

This recently described species is known from Germany, Switzerland, Czech Republic, Slovakia, Romania, Bulgaria (Merz \& Roháček 2005) and Sweden (Roháček 2011). 
Interestingly, the type locality of this species lies not far from the above record (C. Bohemia: Kunice). Adults are known to occur rarely in wet to dry grassland habitats as well as in thin forests, from lowland to submontane altitudes (Merz \& Roháček 2005). There are only a few records from the Czech Republic (both Bohemia and Moravia, see Merz \& Roháček 2005) and the species is considered vulnerable (in "red book") in the country by Roháček (2005a; listed as Stenomicra delicata). The above record from sapping stump is interesting although it could represent an occasional occurrence.

\section{ASTEIIDAE}

\section{Leiomyza dudai Sabrosky, 1956}

Material: 29.v.-3.vii., 1 ㅇ․

The record of this common and widespread Eurasian species is interesting because it is a mycophagous species developing in sporocarps of various fungi (Ševčík 2010).

\section{ACARTOPHTHALMIDAE}

\section{Acartophthalmus bicolor Oldenberg, 1910}

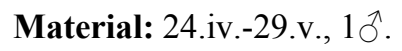

This widespread Holarctic species has necrophagous larvae. Adults can be found on carrion, more rarely also on decaying fungi, both in forested and open habitats. The specimen was surely attracted to meat bait on the stump because it can be easily caught in meat-baited traps (see Roháček et al. 2005a).

\section{CARNIDAE}

\section{Meoneura vagans (Fallén, 1823)}

Material: 24.iv.-29.v., $6 \bigcirc^{\lambda} 1$ ㅇ (1ठำ in cop.), 3.-19.vii., $1 \overbrace{}^{\lambda}$.

A Holarctic species, in Europe not found southerly to Hungary. It is frequent in the Czech Republic (Roháček 1996; Roháček et al. 2005b), relatively eurytopic and probably widely saprophagous (necrophagous-coprophagous) as larva but infrequent in meat-baited traps (Roháček 1996). Therefore, it is interesting that only this single species of Meoneura was recorded in our trap.

\section{MILICHIIDAE}

\section{Milichia ludens (Wahlberg, 1847)}

Material: 3.-19.vii., $1 \hat{\jmath}$.

This temperate and North European species, infrequent in the Czech Republic (cf. Roháček et al. 2005c), is associated with well preserved forested areas. Its saproxylic larvae develop in rotting tree stumps. In the Czech Republic it is classified as vulnerable species (Roháček 2005b).

\section{Desmometopa microps Lamb, 1914}

Material: 3.-19.vii., 10 .

The species, originally widespread in the Oriental, Afrotropical and SE Palaearctic Regions, has recently expanded to Central Europe including the Czech Republic (for previous records see Roháček 2006; Roháček \& Máca 2010). This record confirms the rapid spreading of this alien species in the Czech Republic as presupposed by Roháček (2006). 
Apart from the above listed species, 4 additional species of Milichiidae were recorded in the trap, including the widely saprophagous Desmometopa sordida (Fallén, 1920), Leptometopa latipes (Meigen, 1830) and Madiza glabra Fallén, 1820 but also myrmecophilous Phyllomyza securicornis Fallén, 1823.

\section{TRIXOSCELIDIDAE}

\section{Trixoscelis similis Hackman, 1970}

Material: 3.-19.vii.2010, $1 \hat{\text {. }}$.

A European species, relatively frequent in warm areas of the Czech Republic (cf. Roháček \& Barták 2001; Roháček et al. 2005d). It is clearly associated with forest-steppe habitats. The above record from the trap on stump is interesting although probably occasional.

\section{SPHAEROCERIDAE}

\section{Opalimosina (Hackmanina) czernyi (Duda, 1918)}

Material: 27.iii.-24.iv., $1 \overbrace{}^{\lambda} 1$ ㅇ․

This uncommon transpalaearctic species (cf. Marshall et al. 2011) is restricted to zone of deciduous forests. The above record is interesting for two reasons: (1) it is a woodland species, (2) it is clearly associated with fungi (larval mycophagy was recently demonstrated by rearing from Meripilus giganteus - see Ševčík 2010).

Thirteen additional species of Sphaeroceridae were recorded together with $O$. czernyi, viz. Ischiolepta nitida (Duda, 1920), I. pusilla (Fallén, 1820) (abundant), Sphaerocera monilis Haliday, 1836, Bifronsina bifrons (Stenhammar, 1855), Chaetopodella scutellaris (Haliday, 1836), Coproica hirticula Collin, 1956, C. hirtula (Rondani, 1880), Elachisoma aterrimum (Haliday, 1833), Gonioneura spinipennis (Haliday, 1836), Eulimosina ochripes (Meigen, 1830), Opalimosina (Opalimosina) mirabilis (Collin, 1902), Spelobia clunipes (Meigen, 1830) and Trachyopella (Trachyopella) lineafrons (Spuler, 1925). Most of these largely polysaprophagous species were probably attacted to meat bait in the trap on the stump but the occurrence of Sphaerocera monilis is interesting because it is another infrequent woodland species with distinct preference to rotting sporocarps of fungi.

\section{DROSOPHILIDAE}

\section{Cacoxenus indagator Loew, 1858}

Material: 27.iii.-24.iv., 2q, 24.iv.-29.v., $2{ }^{\Uparrow} 3$ \%

A European species; not yet recorded in Scandinavia but also known from Israel. It is uncommon in the Czech Republic (Máca et al. 2005c) and occurs very locally. Larvae are commensals of larvae in nests of bees (Apidae: Osmia spp., see Baechli et al. 2004) and adults may be attracted to exuding tree sap and were therefore captured in the trap.

\section{Drosophila (Sophophora) tristis Fallén, 1823}

Material: 27.iii.-24.iv., $1{ }^{\lambda}$.

A Palaearctic species, in Europe not recorded from European Russia and in northern Scandinavia, rare in the Czech Republic. It is a stenotopic species occurring predominantly in tree canopies (Baechli at al. 2004) at banks of small woodland creeks but its biology is poorly known.

Apart from the two above mentioned species, 12 additional drosophilid species were trapped. They represent a mixture of 5 common synanthropic species, viz. Drosophila 
(Dorsilopha) busckii Coquillett, 1901, Drosophila (s. str.) funebris (Fabricius, 1787), D. (s. str.) hydei Sturtevant, 1921, D. (s. str.) immigrans Sturtevant, 1921, D. (Sophophora) melanogaster Meigen, 1830, 4 mycetophagous species: Leucophenga maculata (Dufour, 1839), Drosophila (s. str.) limbata von Roser, 1840 , D. (s. str.) testacea von Roser, 1840 and Hirtodrosophila cameraria (Haliday, 1833), 2 species associated with fallen and diseased tree trunks in natural-type forests, viz. Scaptodrosophila rufifrons (Loew, 1873) and Stegana (Steganina) coleoptrata (Scopoli, 1763) and, rather surprisingly, only one species of Chymomyza, viz. C. costata (Zetterstedt, 1838) which otherwise occur commonly on sap runs on wounded trees.

\section{MUSCIDAE}

\section{Phaonia boleticola (Rondani, 1866)}

Material: 11.vii.-11.viii., $10 \hat{\text {. }}$

A temperate West Palaearctic species rarely collected. Its larvae develop in fungi (found in Boletus luridus - cf. Hennig 1955-64).

\section{Phaonia canescens Stein, 1916}

Material: 11.viii.-11.ix., $10^{\lambda} 1$ \%

A Palaearctic species, ranging from Great Britain and Sweden through Central Europe to France, Near East and the Far East of Russia. The puparium was found under bark of fallen pine (Hennig 1955-64); recently the species has been reared from decaying logs of poplars (Gregor et al. 2002).

\section{Potamia littoralis Robineau-Desvoidy, 1830}

Material: 11.vii.-11.viii., 1ठ઼, 11.viii.-11.ix., 9ð, 11.ix.-17.x., $1 \widehat{ }$

A Holarctic species, distributed throughout Europe, also in Myanmar in the Oriental Region. The larva is probably a saprophagous generalist (occasionally predaceous), reared from various decaying organic substrates including fungi and decaying woods. The species is found mostly individually, our records are surprisingly numerous. Adults were probably attracted by meat because they regularly visit cadavers (Hennig 1955-64).

Besides the above mentioned species, the following rare muscids were also found in the trap: Phaonia gobertii (Mik, 1881), Helina latitarsis Ringdahl, 1924 and Eudasyphora zimini (Hennig, 1963).

\section{RHINOPHORIDAE}

\section{Tricogena rubricosa (Meigen, 1824)}

Material: 11.vii.-11.viii., $4{ }^{\lambda} 4$.

A European species. In Central Europe it is rather rare species. Larva parasitizes woodlice (Pape 1998). Interestingly, other two species of Rhinophoridae were found in the trap, viz. Rhinophora lepida (Meigen, 1824) and Melanophora roralis (Linnaeus, 1758).

\section{Discussion and conclusions}

From the above results (though based on records of the most interesting species only), it is obvious that the pyramidal trap, particularly when provided with several different bait media, is capable of capturing very diverse dipterous material, including rare and local species which are otherwise uneasy to find due to their confinement to special microhabitats or breeding 
substrates. In this way the pyramidal trap can rival Malaise traps because it combines the characteristics of the emergence trap, bait trap, and partly intercept or Malaise traps.

This was also demonstrated in our case despite the fact that our results were based only on selected taxa. The most important component of the captured flies was formed by species directly associated with the stump of the European walnut under study, therefore either by those developing in sap runs or attracted as adults to sap [e.g. Syrphidae: Ceriana conopsoides; Aulacigastridae: three species of Aulacigaster spp. including A. falcata; various species of Drosophilidae including Cacoxenus indagator] or those living in dead wood, under bark and in tunnels of other saproxylic insects [Xylomyidae: Solva marginata; several species of Stratiomyidae; Lonchaeidae: a number of species of Lonchaea; Odiniidae: Neoalticomerus formosus; Milichiidae: Milichia ludens; Drosophilidae: Stegana coleoptrata; Muscidae: Phaonia canescens].

In addition, a number of mycophagous species (Asteiidae: Leiomyza dudai; Sphaeroceridae: Opalimosina czernyi, Sphaerocera monilis; Drosophilidae: 4 species including the uncommon Hirtodrosophila cameraria; Muscidae: Phaonia boleticola), necrophagous (Sepsidae: Meroplius minutus, Acartophtalmidae: Acartophthalmus bicolor, Milichiidae: Leptometopa latipes, Madiza glabra) and saprophagous species (various Sepsidae, Carnidae, Milichiidae, Sphaeroceridae) were also caught because they were obviously attracted to meat-bait used in the trap.

Acknowledgements: This paper was supported by research project IRP MSM 6046070901 (Ministry of Education, Sports and Youth) and NAZV project QH 72151 (Ministry of Agriculture, National Agency for Agricultural Research) (both M. Barták) and by the grant No. IGS201103 (Silesian Museum, Opava) (J. Roháček). Prof. Dr. R. Rozkošný, DrSc. is heartily thanked for identification of Stratiomyidae and Xylomyidae and Dr. Jan Máca, Ph.D. for identification of Lonchaeidae, Odiniidae and Drosophilidae.

\section{References}

Baechli G., Vilela C. R., Escher S. A. \& Saura A. (2004): The Drosophilidae (Diptera) of Fennoscandia and Denmark. Fauna Entomologica Scandinavica, Vol. 39, Brill, Leiden-Boston, 362 pp.

Barták M. (1997): The biomonitoring of Diptera by means of yellow pan water traps. In Vaňhara J. \& Rozkošný R. (eds): Dipterologica bohemoslovaca 8. - Folia Fac. Sci. Nat. Univ. Masaryk. Brun., Biologia 95: 9-16.

- (2005): Sepsidae (kmitalkovití). P. 325. In: Farkač J., Král, D.\& Škorpík M., (eds): Červený seznam ohrožených druhů České republiky. Bezobratlí. Red list of threatened species in the Czech Republic. Invertebrates. Agentura ochrany prírody a krajiny ČR, Praha, 760 pp.

Barták M., Frydrych J., Lošák M., Cagaš B., Rotrekl J., Kolařík P. \& Rudišová I. (2008): Diptera families in grassland agroecosystems under different management practices. Pp. 15-25. In Kubík Š. \& Barták M. (eds): Workshop of Animal Biodiversity, ČZU, Jevany, 96 pp.

Barták M., Zeman V. \& Zuska J. (1997): Faunistic records from the Czech and Slovak Republics. Diptera: Sepsidae, Piophilidae, Chloropidae. In Vaňhara J. \& Rozkošný R. (eds): Dipterologica bohemoslovaca 8. - Folia Fac. Sci. Nat. Univ. Masaryk. Brun., Biologia 95: 226-227.

Ferrar P. (1987): A guide to the breeding habits and immature stages of Diptera Cyclorrhapha. Entomonograph 8, pt.1 and pt. 2, E. J. Brill/Scandinavian Science Press, Leiden-Copenhagen, 907 pp.

Gregor F., Rozkošný R., Barták M. \& Vaňhara J. (2002): The Muscidae (Diptera) of Central Europe. - Folia Fac. Sci. Nat. Univ. Masaryk. Brun., Biologia 107: 1-280.

Hennig W. (1955-64): Muscidae. In Lindner E. (ed.): Die Fliegen der Palaearktischen Region, 63b, Schweitzerbart, Stuttgart, $1110 \mathrm{pp}$.

Ježek J. \& Hájek J. (2007): Psychodidae (Diptera) of the Orlické hory Protected Landscape Area and neighbouring areas with descriptions of two new species from the Czech Republic. - Acta Entomol. Mus. Natn. Pragae 47: 237-285.

Kassebeer C. F. (2001): Die einheimische Arten der Gattung Aulacigaster, 1835 (Diptera, Aulacigastridae). - Dipteron (Kiel) 1: 23-32.

Laveissière C. \& Grébaut P. (1990): The trapping of tsetse flies (Diptera: Glossinidae). Improvement of a model: the Vavoua trap. - Trop. Med. Parasitol. 41(2): 185-92. 
Máca J., Kubík Š. \& Barták M. (2005a): Lonchaeidae. Pp. 245-248. In Barták M. \& Kubík Š. (eds): Diptera of Podyjí National Park and its Environs. Česká zemědělská univerzita v Praze, Praha, 434 pp.

- (2005b): Odiniidae. Pp. 283-284. In Barták M. \& Kubík Š. (eds): Diptera of Podyjí National Park and its Environs. Česká zemědělská univerzita v Praze, Praha, 434 pp.

- (2005c): Drosophilidae. Pp. 349-354. In Barták M. \& Kubík Š. (eds): Diptera of Podyjí National Park and its Environs. Česká zemědělská univerzita v Praze, Praha, 434 pp.

MacGowan I. \& Rotheray G. (2008): British Lonchaeidae. Handbooks for the identification of British insects, Vol. 10, part 15, Royal Entomological Society, St. Albans, 142 pp.

Marshall S. A., Roháček J., Dong H. \& Buck M. (2011): The state of Sphaeroceridae (Diptera: Acalyptratae): a world catalog update covering the years 2000-2010, with new generic synonymy, new combinations, and new distributions. - Acta Entomol. Mus. Natn. Pragae 51: 217-298.

Mazánek L. \& Barták M. (2005): Syrphidae (pestřenkovití). Pp. 300-303. In Farkač J., Král, D. \& Škorpík M. (eds): Červený seznam ohrožených druhů České republiky. Bezobratlí. Red list of threatened species in the Czech Republic. Invertebrates. Agentura ochrany př́rody a krajiny České republiky, Praha, $760 \mathrm{pp}$.

McLean I. (2010): Chapter 2. Collecting and recording Diptera. Trapping Diptera. Pp. 95-102. In Chandler P. (ed.): A dipterist's handbook (2nd Edition). The Amateur Entomologist Vol. 15, The Amateur Entomologist's Society, Brentwood, Essex, 525 pp.

Merz B. \& Roháček J. (2005): The Western Palaearctic species of Stenomicra Coquillett (Diptera, Periscelididae, Stenomicrinae), with description of a new species of the subgenus Podocera Czerny. - Rev. suisse Zool. 112(2): 519-539.

Nagatomi A. \& Rozkošný R. (1997): Family Xylomyidae. Pp. 369-378. In Papp L. \& Darvas B. (eds): Contributions to a Manual of Palaearctic Diptera (with special reference to flies of economic importance). Vol. 2. Nematocera and lower Brachycera. Science Herald, Budapest, 592 pp.

Pape T. 1998: 3. 53. Family Rhinophoridae. Pp. 679-689. In Papp L. \& Darvas B. (eds): Contributions to a Manual of Palaearctic Diptera (with special reference to flies of economic importance). Vol. 3. Higher Brachycera. Science Herald, Budapest, 880 pp.

Papp L. (1998): The Palaearctic species of Aulacigaster Macquart (Diptera: Aulacigastridae). - Acta Zool. Acad. Sci. Hung. 43(3)(1997): 225-234.

Pont A. C. \& Meier R. (2002): The Sepsidae (Diptera) of Europe. Fauna Entomologica Scandinavica, Vol. 37, Brill, Leiden-Boston-Köln, 220 pp.

Roháček J. (1996): Fourth supplement to the acalyptrate Diptera fauna of the Czech Republic and Slovakia. Čas. Slez. Muz. Opava (A), 45: 17-28.

- (2005a): Stenomicridae. P. 334. In Farkač J., Král D. \& Škorpík M. (eds): Červený seznam ohrožených druhů České republiky. Bezobratlí. Red list of threatened species in the Czech Republic. Invertebrates. Agentura ochrany př́rody a krajiny České republiky, Praha, 760 pp.

- (2005b): Milichiidae (zavalitkovití). Pp. 338-339. In Farkač J., Král D. \& Škorpík M. (eds): Červený seznam ohrožených druhů České republiky. Bezobratlí. Red list of threatened species in the Czech Republic. Invertebrates. Agentura ochrany př́rody a krajiny České republiky, Praha, 760 pp.

- (2006): Desmometopa microps Lamb, 1914. Pp. 321-322. In Mlíkovský J. \& Stýblo P. (eds): Nepůvodní druhy fauny a flóry České republiky. [Alien species in the fauna and flora of the Czech Republic]. Český svaz ochránců prírody, Praha, 496 pp. (in Czech).

- (2011): Taxonomy of Stenomicra cogani, with description of S. gracilior sp. nov. from Turkey and comparative morphology of terminalia in Stenomicridae (Diptera). - Acta. Entomol. Mus. Natn. Pragae 51(2): 697-722.

Roháček J. \& Barták M. (2001): Trixoscelididae. In Barták M. \& Vaňhara J. (eds): Diptera in an industrially affected region (north-western Bohemia, Bílina and Duchcov environs), II. - Folia Fac. Sci. Nat. Univ. Masaryk. Brun., Biologia 105: 407-409.

Roháček J., Kubík Š. \& Barták M. (2005a): Acartophthalmidae. Pp. 282-283. In Barták M. \& Kubík Š. (eds): Diptera of Podyjí National Park and its Environs. Česká zemědělská univerzita v Praze, Praha, 434 pp.

- (2005b): Carnidae. Pp. 311-315. In Barták M. \& Kubík Š . (eds): Diptera of Podyjí National Park and its Environs. Česká zemědělská univerzita v Praze, Praha, 434 pp.

- (2005c): Milichiidae. Pp. 315-318. In Barták M. \& Kubík Š . (eds): Diptera of Podyjí National Park and its Environs. Česká zemědělská univerzita v Praze, Praha, 434 pp.

- (2005d): Trixoscelididae. In Barták M. \& Kubík Š. (eds): Diptera of Podyjí National Park and its Environs. Česká zemědělská univerzita v Praze, Praha, 434 pp.

Roháček J. \& Máca J. (2010): New and interesting records of Diptera (Asteiidae, Aulacigastridae, Milichiidae, Sphaeroceridae) from the Czech Republic. - Čas. Slez. Muz. Opava (A), 59: 165-170. 
Rozkošný R. (1983): A biosystematic study of the European Stratiomyidae (Diptera). Vol. 2., W. Junk, The Hague-Boston-London, $431 \mathrm{pp}$.

Speight M. C. D. (2003): Species accounts of European Syrphidae (Diptera) 2003. In Speight M. C. D., Castella E., Sarthou J.-P. \& Ball S. (eds): Syrph the Net, the database of European Syrphidae, Vol. 39, Syrph the Net publications, Dublin, 209 pp.

Ševčík J. (2010): Czech and Slovak Diptera assocaited with fungi. Slezské zemské muzeum, Opava, 112 pp.

Walton W. E. (2009): Effectiveness of pyramidal emergence traps for estimating production of Culex mosquitoes (Diptera:Culicidae). - J. North Am. Benthol. Soc. 28(3): 676-682.

\section{Nálezy zajímavých druhů dvoukřídlých (Diptera) přilákaných do pyramidální pasti na mokvajícím paře- zu ořešáku vlašského (Juglans regia) s návnadou hnijícího masa ve středních Čechách (Česká republika)}

Je popsán a vyobrazen nový model pyramidální pasti, která byla instalována nad mokvajícím pařezem ořešáku vlašského (Juglans regia) s návnadou masa na lokalitě Bláto poblíž Uhlířských Janovic ve středních Čechách v roce 2010. Během celosezónní expozice tato past zachytila bohaté druhové spektrum dvoukřídlého hmyzu (Diptera). Je prezentován výčet nálezů 24 druhů zajímavých z faunistického, bionomického nebo ochranářského hlediska s komentáři $\mathrm{k}$ jejich rozš́iření a bionomii, přičemž je zmíněna ještě řada dalších zachycených druhů. Kromě druhů, které se vyvíjejí nebo jsou lákány jako imága na mokvající mízu [např. Syrphidae: Ceriana conopsoides (Linnaeus, 1758), Aulacigastridae: 3 druhy rodu Aulacigaster, různé druhy čeledi Drosophilidae], tvořily další významné složky zachycených dipter druhy saproxylické [Xylomyidae: Solva marginata (Meigen, 1820), několik druhů čeledi Stratiomyidae, četné druhy čeledi Lonchaeidae, Milichiidae: Milichia ludens (Wahlberg, 1847) a některé druhy čeledi Muscidae], mykofágní [některé druhy z čeledí Asteiidae, Sphaeroceridae a Drosophilidae], nekrofágní [několik druhů z čeledí Sepsidae, Acartophtalmidae, Milichiidae, Sphaeroceridae] a široce saprofágní [některé druhy z čeledí Sepsidae, Carnidae, Milichiidae, řada druhů čeledi Sphaeroceridae], při čemž poslední dvě skupiny byly zřejmě přilákány na masovou návnadu, která byla $\mathrm{v}$ pasti také použita. Nález druhu Aulacigaster falcata Papp, 1998 (Aulacigastridae) je prvním záznamem výskytu v Čechách.

Authors' addresses: Miroslav Barták, Czech University of Life Sciences, Faculty of Agrobiology, Food and Natural Resources, Department of Zoology and Fisheries, 16521 Praha 6 - Suchdol, Czech Republic. E-mail: bartak@af.czu.cz Jindřich Roháček, Slezské zemské muzeum, Tyršova 1 CZ - 74646 Opava, Czech Republic. E-mail: rohacek@szmo.cz 